\title{
Total Quality Management and the Role of Management Accountants on Organisational Performance: The Service Sector in Malaysia
}

\author{
Gheyath Ghassan, Ruhanita Maelah*, Amizawati Mohd Amir and \\ Mohammed Fadhil Farhan
}

\begin{abstract}
Manuscript type: Research paper

Research aims: This study examines the relationship between total quality management (TQM), the role of the management accountant and organisational performance among the service sector in Malaysia.

Design/Methodology/Approach: This study collects data from 100 private service organisations in Malaysia via a self-administered printed questionnaire. Data collected are analysed using partial least squares (PLS) 3.0.

Research findings: The results reveal that TQM has a positive significant impact on organisational performance. The TQM's practice of focussing more on customers and the designing of services also show significant effects on organisational performance. This study finds that management accountants do not moderate the relationship between TQM and organisational performance.
\end{abstract}

* Corresponding author: Ruhanita Maelah is an Associate Professor at the Faculty of Economics and Management, Universiti Kebangsaan Malaysia, Malaysia. Email: ruhanita@ ukm.edu.my

Gheyath Ghassan is a Master of Accounting Scholar at the Faculty of Economics and Management, Universiti Kebangsaan Malaysia, Malaysia. Email: gheyath.ghassan@warbaco.com Amizawati Mohd Amir is an Associate Professor at the Faculty of Economics and Management, Universiti Kebangsaan Malaysia, Malaysia. Email:amiza@ukm.edu.my

Mohammed Fadhil Farhan is a Master of Accounting Scholar at the Faculty of Economics and Management, Universiti Kebangsaan Malaysia, Malaysia. Email: muhammed_fadil@yahoo.com

https:// doi.org/10.22452/ajba.vol12no2.6 
Theoretical contribution/Originality: This study expands the previous literature by examining the role of the management accountant as a moderator between TQM and organisational performance.

Practitioner/Policy implications: The results derived from this study can be used to facilitate the application of TQM in service organisations so as to enhance their organisational performance. The findings can also assist managers in the service organisations to determine the functions of their management accountants because this can impact on the successful adoption of TQM.

Research limitation/Implications: The limitations of this study includes its scope which is confined to only the service industry. Future research should expand further to cover other industries.

Keywords: TQM, Organisational Performance, Role of the Management Accountant, Service

JEL Classification: M41

\section{Introduction}

Globalisation, rapid growth of technology, and changes in the sociopolitical and economic environment have intensified competition and developed more challenges for businesses in the market. To sustain themselves, these businesses need to address those increasing pressures that consumers and competitors alike have placed on them, for instance, to improve their product standards and service quality (Muturi, Ochieng, \& Njihia, 2015; Mahmood, Mahmood, Qureshi, \& Nisar, 2014). Service quality is becoming a significant issue to organisations because it enables organisations to remain competitive and to excel. These practices are thus applied and implemented by service organisations so as to gain a competitive edge over others (Bon \& Mustafa, 2013). To be able to offer quality services, these service organisations need to be proactive at an opportune time with appropriate prices (Mohd Amir, Nik Ahmad, \& Har Sani Mohamad, 2010). This has to be the strategy because better service quality coupled by lower prices would improve an organisation's competitiveness, hence increase customer satisfaction (Kumar, Garg \& Garg, 2011).

The service sector has a vital role to play in industrialised economies (Hasan \& Kerr, 2003; Ismail, Yussof, \& Uddin, 2012; Lam, Lee, Ooi, \& Phusavat, 2012). It was observed that in 2016, about half or 54 per cent of Malaysia's GDP was contributed by the service sector (Ministry of Finance Malaysia, 2016). By 2020, the service sector is expected to 
improve its contribution to the GDP even more, around 58 per cent (Ministry of International Trade and Industry, 2013). Despite the crucial role it plays in the Malaysian economy, the service sector has largely been overlooked by research (Muzamil Naqshbandi \& Idris, 2012; Mohd Amir et al., 2010) with only a few studies that had examined total quality management (TQM) among the service industry of Malaysia.

Despite its manufacturing origins (Mohanty \& Behera, 1996) which began in the past 15 years, the TQM principles and practices also have been applied by academics and practitioners within the service sector (Silvestro, 1998). Some service organisations from a variety of service industries, such as healthcare, insurance and hospitality have shown an interest in TQM in recent years (Yasin, Alavi, Kunt, \& Zimmerer, 2004). The reason is because TQM promotes the effective management of service organisations; it is also one of the causal factors for business excellence (Calabrese \& Corbò, 2015).

TQM has been identified to be the most successful approach in managing products and service quality and it has also helped to improve companies' competitiveness globally (Sweis et al., 2016). TQM has also been noted to enable firms to reduce costs and to increase the productivity of the physical and human organisational assets (Sweis et al., 2016). TQM is an organisational-wide philosophy that is constantly applied by firms so as to improve the quality of their products, services and also the processes involved. Firms are encouraged to focus on consumers' requirements in anticipation of greater customer satisfaction and organisational performance (Sadikoglu \& Olcay, 2014). In recent years, TQM has also been regarded as one of the more advanced management accounting practices (Tuanmat \& Smith, 2011; Nuhu, Baird, \& Appuhami, 2016; Ross \& Kovachev, 2009; Ayedh \& Houssem, 2015).

Most literature (Chong \& Rundus, 2004; Chenhall, 1997; Kaynak, 2003; Baird, Jia Hu, \& Reeve, 2011; Al-Dhaafri, Al-Swidi, \& Yusoff, 2016) have stated that the relationship between TQM and organisational performance is positive and significant. However, other studies found adverse results (e.g. Kober, Subraamanniam, \& Watson, 2012). These inconsistent results have caused previous researchers to concentrate on factors that prevent organisations from achieving the benefits of TQM. Tatikonda and Tatikonda (1996) identified the usual characteristics of TQM adopters which did not experience a huge increase in their organisations' quality and profitability. These factors were found to include insufficient customer focus, insufficient management commitment and involvement, meaningless trainings, inadequate costs 
and benefit analyses, absence of an organisational structure that supports TQM implementations, trivial bureaucracy, inadequate or wrong measurements, unsuitable rewards and recognitions, followed by outdated accounting systems. Other studies such as those by Nicolaou and Kentas (2017) reviewed the healthcare sectors' failure for TQM implementation; Talib and Rahman (2015) prioritised and ranked the barriers for TQM implementations within the service industry by using an analytic hierarchy process (AHP) approach while Mosadeghrad $(2013$, 2014) related successful TQM implementation needs sufficient education and training, supportive leadership, consistent support of top management, customer focus, employee involvement, process management and continuous improvement of processes; and Talib, Rahman and Qureshi (2013) found that quality culture was perceived as the dominant TQM practice.

Cockrell and Meyer (2012) stated that management accountants can play a crucial role in making tremendous contributions towards organisation performance by manifesting their ability to recognise those factors that contribute to TQM failures. Management accountants are important individuals of an organisation. They have the competence to contribute towards their firms' performance because they have the understanding about the best cost accounting practices, they possess various computer application skills, they are good team players, they have the highest knowledge about their company's operations and other business matters, they play the role and have the assured responsibility to participate in strategic decision-making of the company, and they also have the cognitive abilities to undertake the thinker's role. The worldwide adoption of TQM allows management accountants to continuously enhance their companies' quality improvement activities through contemporary and modern methods (Cockrell \& Meyer, 2012). On the same note, Manners (2006) had also posited that management accountants can provide the decision-support environment for the firm's continuous improvement. The function of TQM includes managing the past, the present and the future costs of the firm through systematic managerial accounting, cost accounting and general accounting (Chen, 2016).

Previous studies have examined the transformation of management accountants' role without examining its relationship with other variables including TQM. Furthermore, how the role of management accountants have changed and developed within an organisation have not been thoroughly explored. Previous studies (De Loo, Verstegen, \& 
Swagerman, 2011; Goretzki, Strauss, \& Weber, 2013; Byrne \& Pierce, 2007) have suggested that insights into the changes of management accountants is still insufficient while there is still much debate about management accountants and their functions within organisations. This study argues that service organisations' performance may be influenced by TQM and management accountants. Specifically, the objectives of this study are to analyse the effect of TQM on organisational performance, and to examine the moderating effect of the management accountant's role on the association between TQM and organisational performance. The resource-based view (RBV) is utilised as the underlying theory in the framework.

This paper is organised in the following manner. Section 1 presents the background of the investigated concepts. Section 2 reviews the related literature leading to the theoretical framework for the research methodology. Section 3 discusses the methodology employed. Section 4 presents the results, analyses and the findings while Section 5 presents the research implications, constraints and proposals for future studies.

\section{Literature Review}

\subsection{Total Quality Management (TQM)}

Although TQM has been discussed in management literature, it is recently viewed as an advanced management accounting practice (Wickramasinghe \& Alawattage, 2007; Yazdifar \& Tsamenyi, 2005; Yazdifar, Askarany, \& Askary, 2008). Advanced management accounting practices are established in order to remove the constraints of conventional management accounting practices, and to fulfil the requests of the evolving business environment (Nuhu et al., 2016).

Research on TQM as noted in the management accounting literature is limited. Ittner and Larcker (2001) postulated that studies looking at the interaction between accounting and operations management, such as TQM (Muhammad Zawawi \& Hoque, 2010) have significantly decreased due to the growing interest on "new" areas, such as intangible assets, balanced scorecard (BSC), and economic value added. Muhammad Zawawi and Hoque (2010) reviewed the research done on management accounting innovation and noted that studies in this area were limited with some studies focusing on the relationship between TQM and management accounting (Gurd, Smith, \& Swaffer, 2002; Emsley, 2008). These studies focused on either management accounting system in TQM's environment or costs and outcomes related to quality. 
TQM practices include corporate planning, top management leadership, customer focus, human resource focus, process focus, quality focus, and information and analysis (Brah, Wong, \& Madhu Roa, 2000). Other studies like Flynn, Sakakibara and Schroeder (1995) and Chong and Rundus (2004) mentioned that TQM can be measured through two practices - customer focus, and product/service designs. Customer focus involves producing and delivering products and services that fulfil the demands and anticipation of customers for the present and future (Sadikoglu \& Zehir, 2010). Service design is the attempt to fulfil lucidity in terms of services and process design specifications before offering the services to the market (Baird et al., 2011). The main feature of quality management is for firms to have a solid relationship with the customers, hence customers' requirements are recognised and addressed (Sit, Ooi, Lin, \& Chong, 2009). For firms to be able to offer services or products that fulfil or even exceed customers' expectations, top managers need to integrate customers' recommendations into their service designs (Mahmood et al., 2014).

To date, only a few empirical studies on TQM have been carried out in the ASEAN region (Lam et al., 2012). For Malaysia, the implementation of TQM is still problematic (Mahmud \& Hilmi, 2014), with only a few empirical studies (Idris, 2011; Sohail \& Hoong, 2003) that had focused on TQM practices and organisational performance.

\subsection{TQM and Organisational Performance}

Organisational performance is defined as the result of the operations performed by organisational members (Ramayah, Samat, \& Lo, 2011). To date there are mixed results in the relationship between TQM and organisational performance although most studies have revealed positive findings. For instance, Chenhall (1997) found that performance can be enhanced when there were links between TQM programmes and dependence on manufacturing performance measures. The study by Dunk (2002) showed that product quality can positively enhance quality performance. Chong and Rundus (2004) suggested that highly competitive markets had a greater positive association between TQM practices of customer focus, and product designs, with business performance. Hamza and Al-Kassar (2015) indicated that companies that applied the TQM system gained many benefits, such as better market ranking, improved market shares, better production efficiency and reduced costs. However, the research by Kober et al. (2012) found no proof 
of the positive relationship between TQM and financial performance (after controlling age, sector, size and threats). Similarly, Corredor and Goñi (2011) observed that the adoption of the TQM system had no huge impact on company performance.

\subsection{Role of the Management Accountant}

The tasks of the management accountant are varied and many. Traditionally, a management accountant collects, interprets and discloses financial data to the organisation (Ramli, Zainuddin, Sulaiman, \& Muda, 2013). The emerging "philosophies" of management, such as TQM and continuous improvements, are becoming a component of the management accounting system that gives financial and non-financial data (Wickramasinghe \& Alawattage, 2007). The management accounting system fulfils the requirement for information that upholds culture and which emphasises on quality (Sharma \& Suva, 2000). As a result of this, we can see changes occurring in the functions of the management accountants, moving from assessing and disclosing business activities to collaborating with those of management science, sales, finance and other experts in the implementation of contemporary management measures, such as TQM (Albright \& Lam, 2006; Fowler, 1999). In this context, management accountants are becoming business analysts as well as internal advisors of the organisation rather than just as a support staff who provides the line managers with supplementary services (Yazdifar \& Tsamenyi, 2005; Wickramasinghe \& Alawattage, 2007; Rahman $\&$ Ahmed, 2012). The function description applied on management accountants today include "business partners" or "internal advisors" because their job is to facilitate the management's openness in the decision-making process (Hiebl, Duller, \& Feldbauer-Durstmuller, 2012; Zainuddin \& Sulaiman, 2016; Ramli et al., 2013).

Several studies (Ramli et al., 2013; De Loo et al., 2011; Byrne \& Pierce, 2007; Sunarni, 2013; Yazdifar \& Tsamenyi, 2005; Mistry, Sharma, \& Low, 2014; Paulsson, 2012; Collins, Lawrence, Roper, \& Haar, 2011) have discussed the role of the management accountants in their organisations from several per-spectives. Despite this, few have discussed or analysed the functions of the management accountant in quality management programmes. As an example, Fowler (1999) reviewed the function of the management accountants in quality control and it was noted that management accountants also include the TQM concepts in their accounting tasks. An accountant interviewed 
by Sharma, Lawrence and Lowe (2010) had also stated the heavy adoption of TQM practices as part of their jobs. Most of the management accountants interviewed by Hoque and Alam (1999) believed that management accountants have a vital function in assisting companies to achieve their goals through their provision of various TQM-related measures and reports. Cockrell and Meyer (2012) had discussed the functions of management accountants with regards to TQM. They argued that the TQM's implementation success, and the handling of TQM issues are contributions made by management accountants (see Table 1), as identified by Tatikonda and Tatikonda (1996).

Table 1: Role of Management Accountants in TQM

\begin{tabular}{|c|c|}
\hline Potential reasons for failure & Prevention strategies \\
\hline Lack of customer focus & $\begin{array}{l}\text { - Promoting the service mentality internally } \\
\text { and externally } \\
\text { - Link financial data to customer satisfaction } \\
\text { - Assist others in measuring satisfaction }\end{array}$ \\
\hline $\begin{array}{l}\text { Lack of management } \\
\text { commitment and } \\
\text { involvement }\end{array}$ & $\begin{array}{l}\text { - Lead by example (attitude and actions) } \\
\text { - Serve as a quality mentor for the executive } \\
\text { team }\end{array}$ \\
\hline $\begin{array}{l}\text { Dysfunctional structures, } \\
\text { processes and relationships }\end{array}$ & $\begin{array}{l}\text { - Eliminate departmental barriers } \\
\text { - Eliminate items which do not add values } \\
\text { including unnecessary bureaucracy }\end{array}$ \\
\hline $\begin{array}{l}\text { Lack of cost and benefit } \\
\text { analysis }\end{array}$ & $\begin{array}{l}\text { - Assist with cost analysis } \\
\text { - Teach others how to use analysis } \\
\text { - Integrate the use of financial and quality tools } \\
\text { - Estimates effect of quality initiatives on } \\
\text { - } \text { Asofitability } \\
\text { - } \text { Identify differences between process } \\
\text { measures and outcomes }\end{array}$ \\
\hline $\begin{array}{l}\text { Human resources (HR) } \\
\text { issues and processes, } \\
\text { training, rewards and } \\
\text { recognition, performance } \\
\text { appraisals, job descriptions }\end{array}$ & $\begin{array}{l}\text { - Identify training needs } \\
\text { - Ensure that training reflect actual work } \\
\text { practice } \\
\text { - Align HR processes to support quality } \\
\text { efforts } \\
\text { - Take care of employees } \\
\text { - Ensure data is reliant and reliable } \\
\text { - Share financial data }\end{array}$ \\
\hline
\end{tabular}

Source: Cockrell and Meyer (2012). 


\section{Theoretical Framework}

This study uses the RBV theory as the framework to show how an organisation can gain competitive advantages through its resources and capabilities (Kamboj, Goyal, \& Rahman, 2015). In their study, Amit and Schoemaker (1993) had defined resources as the readily obtainable factors possessed and managed by a company, which are then transformed into final products or services. Barney (1991) argued that a company's resource will create a greater competitive advantage when it is priceless, scarce, expensive to copy and has no substitute.

Powell (1995) and Dubey (2015) were able to provide some empirical evidence showing that TQM could act as a source for companies to gain a competitive and sustainable advantage. TQM can be considered as an intangible resource which could lead firms or companies to achieve a competitive advantage (Al-Dhaafri et al., 2016). This was also supported by Tena, Llusar and Puig (2001) who asserted that the enhancement of firm performance through TQM is due to its encouragement in asset improvement, namely assets that are distinctive. TQM also creates intricate social relationships, is deeply ingrained in the company's history and culture, and creates implicit knowledge. All these characteristics of TQM allow the company to sustain its competitive advantage. Furthermore, TQM is difficult to be copied by rivals since it allows the creation and isolation of mechanisms. It also appears that TQM practices cause continuous improvements, thus it presents a moving target for competitors (Powell, 1995; Flynn, Schroeder, \& Sakakibara, 1994).

Capabilities refer to the company's ability to effectively and efficiently utilise resources to gain desired results (Idris, 2011). The company's capability enables its resources to be used and the possibility of creating outputs (Akio, 2005). Capabilities may consist of skills such as technical or managerial skills; capabilities may also infer knowledge, experience, and know-how that enables the individual to do things well (Wade \& Hulland, 2004; Foss, 1997). However, organisational success is dependent on the involvement of all levels, hence facilitating the TQM tools and techniques to sustain the company's competitive advantage. As a result of the company's abilities, TQM may serve as the company's culture to improve the company's performance (Yunis, Jung, \& Chen, 2013). In line with previous studies (Annamalai \& Ramayah, 2013; Martín-De Castro, Delgado-Verde, Navas-López, \& Cruz-González, 2013; Ortega, 2010), our study considers capability as a moderator 


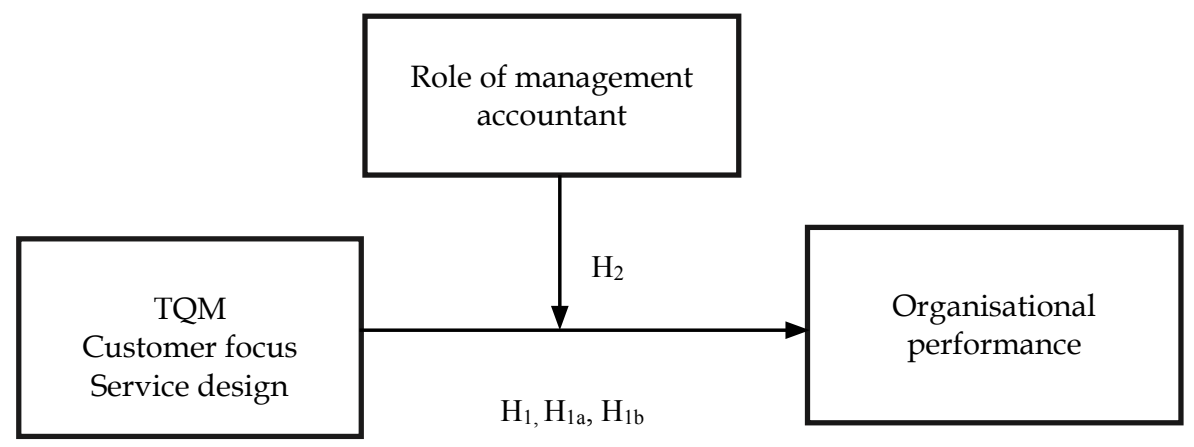

Figure 1: Research Framework

variable based on the RBV. In our study, capability is represented by the management accountant's role. The research framework is thus presented in Figure 1.

In explaining the relationship between the variables, there are two hypotheses formulated. Chenhall (1997) had concluded that TQM provides the possibility for a company to improve its profitability by helping managers to develop quality as a competitive advantage. Kober et al. (2012) also argued that the success of TQM implementation should result in an enhanced service quality. Thus, TQM positively affects both sales and profitability. Amir and Reiche (2013) stated that TQM adoption that is successful could bring in greater performance benefits to the company, including growth and efficiency, improved productivity and innovation, and increased profits and market share. As such, the hypothesis developed for our study is as follows:

$\mathrm{H}_{1}$ : There is a positive relationship between TQM and organisational performance.

In any business, customer focus is a company's vital feature that promotes customer satisfaction (Terziovski, 2006; Meftah Abusa \& Gibson, 2013). This was confirmed by Sit et al. (2009) who found that customer focus has a tremendous impact on customer satisfaction. Ittner and Larcker (1996) suggested that through great customer satisfaction, organisations can increase their profits via cost reduction as a result of lesser product returns, and an increase in revenues due to customer loyalty. Seetharaman, Sreenivasan and Lim (2006) stated that in any organisation, customer satisfaction is the key to gain profits while Sadikoglu and Olcay (2014) asserted that customer focus has a 
positive effect on firm growth/share, profitability, and it is a means of performance improvement, such as loyalty. Therefore, the hypothesis is proposed as follows:

$\mathrm{H}_{1 \mathrm{a}}$ : There is a positive relationship between customer focus and organisational performance.

Flynn et al. (1994) postulated that intact products or service designs that meet customer requirements can lead to an increase in market shares. Baird et al. (2011) stated that to include customers in the process of product/service designs, one way is to integrate their expectations into the development of a new service. This would enhance the firm's service features, and serviceability which can eventually improve quality performance. Calabrese and Corbò (2015) stated that an effective service design could lead to greater company performance, customer contentment, and employee involvement, and subsequently, some other common results of TQM. Based on these arguments, we hypothesise that:

$\mathrm{H}_{1 \mathrm{~b}}$ : There is a positive relationship between service design and organisational performance.

According to the Institute of Management Accountants (IMA), the executive quality council may regard a management accountant as an excellent contributor. This is because a management accountant has the necessary skills of identifying areas that have the best opportunity for quality enhancement, and for establishing a quality measure system to observe progress against quality targets. Hamilton-Smith and Morris (1993) suggested that the management accountant could help the management in implementing the quality strategy through their skills. Margavio, Margavio and Fink (1995) had observed that management accountants are being called to assist in quality management decisions. This is because they are in the quality team, and they participate in the TQM implementation as advisers (Fowler, 1999). Cockrell and Meyer (2012) had noted that management accountants are distinctively qualified to function, and to assist their organisations in achieving performance excellence. They fulfil this part of their responsibility through their contributions towards the successful implementation of TQM. Based on these arguments and on previous literature, the hypothesis is proposed as follows:

$\mathrm{H}_{2}$ : The role of the management accountant moderates the association between TQM and organisational performance. 


\section{Methodology}

\subsection{Population and Data Collection}

The target population for this study comprises 100 private service companies operating in Malaysia. They include finance companies, higher learning institutions, distribution and logistics companies, legal and accounting companies, and other service related organisations. The sampling frame of this study is the Malaysia Services Directory which showcases Malaysian companies that are registered with the Malaysia External Trade Development Corporation (MATRADE). The database can be accessed from the website, "http://www.matrade.gov. my/en/malaysian-exporters/showcasing-malaysia-export/directory/ malaysian-services-directory". The number of available companies in MATRADE as of 1 December 2016 was 8,119. Samples were randomly selected using stratified random sampling. A random sample from each stratum was taken in a number that is proportional to the stratum's size when compared to the population. The advantage of using stratified random sampling is that it provides the same opportunity to all the population units to be included in the selected samples. This offers a high level of generalisability (Bryman \& Bell 2011). The database also provides the websites, email addresses, and the addresses of those companies. The sample size was determined using the table of Krejcie and Morgan (1970). The targeted sample size of 367 companies was based on the minimum number of cases needed for the selected method analysis. Kent (2001) had suggested that to obtain a sensible statistical analysis and significant results, a minimum of 100 cases is needed for any kind of quantitative analysis.

In this study, survey questionnaire was used to collect data based on past studies' approach (Ooi, Lin, Tan, \& Chong, 2011; Psomas \& Jaca, 2016; Lam et al., 2012). The self-administered printed questionnaire was employed for the purpose of obtaining information from respondents who represent companies which have the intention of obtaining the ISO 9001 certification or they have already obtained the ISO 9001 certification. Similar to the approach used by Sunarni (2013), every organisation in this study was given one questionnaire, and a letter explaining the study's goal, and a promise of confidentiality. Before distributing the questionnaires, the respondents were asked if they apply TQM in their organisations. This screening question helps to ensure that the participating organisations only include those that practise TQM. Questionnaires were directed to the heads of the 
accounting department as they are expected to have the vision of their organisational performance. A total of 367 printed questionnaires were distributed by-hand to those companies that had been identified. With a response rate of 27 per cent, this study managed to secure 100 responses. All responses were usable for data analysis.

To improve the questionnaire's design and focus, a pre-test and a pilot test were performed before the actual data collection. For the pre-test, three questionnaires were given to three academics with background in management accounting, from the National University of Malaysia to review the questionnaire for clarity of the items used and their relevance. Feedback about the items and relevance was used to improve the questionnaire. Following this, a pilot test was conducted where five sets of the revised questionnaires were given to representatives from the service organisations within the sampling frame to see if they were able to answer the questionnaire. The representatives completed the questionnaires without any further suggestions for amendments. Therefore, their responses are included as part of the actual data analysis.

\subsection{Measurement of Variables}

To develop the questionnaire for the measuring the TQM, we adopted the questions established by Flynn et al. (1995) and adopted by Chong and Rundus (2004). They were modified for use by the current study. The five-point scale was used as responses for the respondents to indicate the TQM practices of two features: customer focus which has three items, and service design which has seven items. The scales ranged from "strongly disagree" to "strongly agree". Each respondent was required to rate every item of the two features. Five items were used to measure the functions of the management accountant. A five-point scale bounded by "never" and "very frequently" was used to evaluate the five items which also represented the five roles. Each respondent or the individual who performed the management accountant's functions was asked to indicate the relevance of the management accountant for five typical roles. Three of these roles or items (advisor/internal consulting, business analyst, and business partner) were adapted from Malmi, Seppala and Rantanen (2001) and Yazdifar and Tsamenyi (2005) while the two additional roles or items (value creator and decision enabler) were adapted from other related literature (Zainuddin \& Sulaiman, 2016; Sulaiman, Ramli, \& Mitchell, 2008; Rahman \& Ahmed, 2012; Hiebl et al., 2012; Ramli et al., 
2013; Paulsson, 2012). Seven items were used to measure organisational performance. All of them had been developed by Coo and Verma (2002) and modified by Ramayah et al. (2011). Respondents must indicate the performance of their companies over the last three years using the fivepoint scale instrument ranging from "greatly decreased" to "greatly increased".

\section{Data Analysis}

Descriptive analysis was run to analyse the demographic profiles of the respondents and service companies that participated in this study. Table 2 presents the demographic characteristics of the respondents according to their age, level of education, specialisation, current position and

Table 2: Demographic Characteristics of the Respondents and Organisations

\begin{tabular}{lcc}
\hline Demographic Characteristics & Frequency & Percentage (\%) \\
\hline Age & 32 & 32 \\
Under 30 & 50 & 50 \\
$30-40$ & 14 & 14 \\
$41-50$ & 4 & 4 \\
Over 50 & & \\
\hline Education \& Qualification & 23 & 23 \\
College diploma & 46 & 46 \\
Bachelor's degree & 14 & 14 \\
Post graduate & 17 & 17 \\
Professional qualifications & & \\
\hline Job Title & 3 & 3 \\
General Manager/CEOs & 15 & 15 \\
Managerial Accountant & 42 & 7 \\
Account/finance manager & 7 & 33 \\
Quality Manager & 33 & \\
Others* & & 53 \\
\hline Specialisation & 53 & 17 \\
Accounting/Finance & 17 & 10 \\
Business Administration & 10 & 20 \\
Marketing & 20 & 34 \\
Others & & 38 \\
\hline Experience & 34 & \\
Less than 5 years & 38 & \\
5-10 years & & \\
\hline
\end{tabular}


Table 2: (continued)

\begin{tabular}{|c|c|c|}
\hline Demographic Characteristics & Frequency & Percentage $(\%)$ \\
\hline $11-15$ years & 14 & 14 \\
\hline $16-20$ years & 9 & 9 \\
\hline Over 20 years & 5 & 5 \\
\hline \multicolumn{3}{|l|}{ Industry } \\
\hline Business Services & 20 & 20 \\
\hline ICT & 18 & 18 \\
\hline Education Services & 10 & 10 \\
\hline Entertainment & 9 & 9 \\
\hline Architectural Services & 7 & 7 \\
\hline Other Professional \& Technical Services & 7 & 7 \\
\hline Construction and Related Services & 5 & 5 \\
\hline Health Services & 5 & 5 \\
\hline Oil and Gas Services & 4 & 4 \\
\hline Support Services & 4 & 4 \\
\hline Distribution and Logistics Services & 3 & 3 \\
\hline Engineering Services & 2 & 2 \\
\hline Environment Protection Services & 2 & 2 \\
\hline Financial Services & 1 & 1 \\
\hline Franchise & 1 & 1 \\
\hline Legal and Accounting Services & 1 & 1 \\
\hline Printing and Publishing Services & 1 & 1 \\
\hline \multicolumn{3}{|l|}{ Number of Employees } \\
\hline 5 to 29 & 53 & 53 \\
\hline 30 to 75 & 22 & 22 \\
\hline Over 75 & 25 & 25 \\
\hline \multicolumn{3}{|l|}{ Annual Sales Turnover } \\
\hline RM300,000 to RM3 million & 56 & 56 \\
\hline RM3 million to RM20 million & 35 & 35 \\
\hline Over RM20 million & 9 & 9 \\
\hline \multicolumn{3}{|l|}{ Status } \\
\hline ISO 9001 certified & 42 & 42 \\
\hline Planning for ISO 9001 certification & 58 & 58 \\
\hline \multicolumn{3}{|l|}{ Company's Age } \\
\hline Less than 5 years & 9 & 9 \\
\hline 5-10 years & 30 & 30 \\
\hline $11-20$ years & 36 & 36 \\
\hline More than 20 years & 25 & 25 \\
\hline
\end{tabular}

Note: ${ }^{*} 55 \%$ of this group are managers, directors or administrators. 
length of experience in their current position. The results show that a majority of the respondents are in the age range of 30-40 years old (50\%); hold a bachelor's degree qualification (46\%), specialised in the area of accounting/finance (53\%), hold positions as account/finance manager (42\%); and have 5 to 10 years work experience.

Table 2 also presents the demographic characteristics of the companies according to industry, number of employees, annual sales turnover, the status of the firm in terms of ISO 9001 certification and company's age. Most of the participating companies are involved with business services $(20 \%)$, have between 5 to 29 employees $(53 \%)$; have an annual sales turnover between RM300,00 to less than RM3 million $(56 \%)$, are planning for ISO 9001 certification (58\%), and have been in the service industry for 11-20 years (42\%). The descriptive analysis of the companies shows that the sample for the study is well represented in terms of industry type, size, ISO 9001 status and length of period in business.

\subsection{Measurement Model Analysis}

SmartPLS 3.0 software was used to assess the measurement's validity and reliability. Cronbach's alpha and composite reliability values less than 0.6 would signal a reliability problem (Hair, Ringle, \& Sarstedt, 2011). As shown in Table 3, all the variables have values exceeding 0.70 indicating that the items used are reliable.

Convergent validity occurs when every measurement item has a strong correlation with its respective theoretical constructs while discriminant validity exists when every measurement item has a weak correlation with all the other constructs, excluding the one it is theoretically linked to. Certain aspects of the goodness of fit of the measurement model were captured by the two validities (Gefen \& Straub, 2005). To examine the convergent validity, the factor loadings of every item and the average variance extracted (AVE) were obtained. Values that exceeded 0.50 are required to ensure practical significance (Psomas \& Jaca, 2016). Two items from the service design dimension and two items from organisational performance were omitted due to low loadings (Table 4). A construct's convergent validity is satisfactory when its AVE value exceeds 0.5. This indicates that on average, more than half of the indicators' variance can be explained by the latent variable (Ifinedo, 2011; Hair et al., 2011). As shown in Table 3, the AVE of this study persistently exceeded 0.5 . 
Table 3: Convergent Validity

\begin{tabular}{llllll}
\hline Constructs & $\begin{array}{c}\text { Initial } \\
\text { loadings }\end{array}$ & Modified & $\begin{array}{c}\text { Cronbach's } \\
\text { alpha }\end{array}$ & $\begin{array}{c}\text { Composite } \\
\text { reliability }\end{array}$ & AVE \\
\hline Customer focus & & & 0.867 & 0.919 & 0.792 \\
CF1 & 0.825 & 0.825 & & & \\
CF2 & 0.910 & 0.910 & & & \\
CF3 & 0.932 & 0.932 & & & 0.642 \\
\hline Service design & & & 0.857 & 0.899 & \\
SD1 & 0.256 & deleted & & & \\
SD2 & 0.801 & 0.819 & & & \\
SD3 & 0.786 & 0.783 & & & \\
SD4 & 0.663 & 0.639 & & & \\
SD5 & 0.360 & deleted & & & \\
SD6 & 0.863 & 0.873 & & & \\
SD7 & 0.843 & 0.870 & & & \\
\hline Role of manage- & & & 0.762 & & \\
ment accountant & & & & & \\
ROMA1 & 0.568 & 0.559 & & & \\
ROMA2 & 0.796 & 0.806 & & & \\
ROMA3 & 0.686 & 0.660 & & & \\
ROMA4 & 0.788 & 0.793 & & & \\
ROMA5 & 0.708 & 0.707 & & & \\
\hline Organisational & & & 0.835 & & \\
performance & 0.226 & deleted & & & \\
OP1 & 0.309 & deleted & & & \\
OP2 & 0.820 & 0.804 & & & \\
OP3 & 0.759 & 0.782 & & & \\
OP4 & 0.786 & 0.807 & & & \\
OP5 & 0.689 & 0.705 & & & \\
OP6 & & & & & \\
\hline
\end{tabular}

Discriminant validity occurs when the constructs are similar to each other (Straub, Bourdreau, \& Gefen, 2004).). This was asserted by Fornell and Larcker (1981) who mentioned that there is discriminant validity when the AVE exceeds the threshold value of 0.50 , and when all constructs' square root of the AVE is higher when compared to all other cross-correlations. Table 4 confirms that no correlation between the constructs exceeded the square root of the AVE. Therefore, the discriminant validity in this study is adequate for all the constructs. 
Table 4: Discriminant Validity (inter correlation) of the Variable Constructs

\begin{tabular}{lllll}
\hline Constructs & CF & OP & RMA & SD \\
\hline Customer focus (CF) & $\mathbf{0 . 8 9 0}$ & & & \\
Organisational performance (OP) & 0.428 & $\mathbf{0 . 7 7 7}$ & & \\
Role of management accountant (RMA) & 0.181 & 0.221 & $\mathbf{0 . 7 1 1}$ & \\
Service design (SD) & 0.555 & 0.511 & 0.085 & $\mathbf{0 . 8 0 1}$ \\
\hline
\end{tabular}

Overall, this study's measurement items demonstrate good reliability as well as good convergent and discriminant validities.

\subsection{The Structural Model}

The second step of the PLS is the examination of the structural model. It involves estimating the path coefficients $(\beta)$, and the squared $R\left(R^{2}\right)$. Path coefficients show the relationship's strength of the independent and dependent variables (Ko, Kirsch, \& King, 2005). The $\mathrm{R}^{2}$ shows the percentages of the variance explained by the explanatory variables (Soltanizadeh, Abdul Rasid, Mottaghi Golshan, \& Wan Ismail, 2016). The threshold level for $\mathrm{R}^{2}$ value is 0.1 (Camisón \& López, 2010). The path significance level is examined by obtaining the $t$-values from the bootstrapping method in the PLS. In general, an acceptable $t$-value is one that is larger than 1.96 (t-value $>1.96$ ), which means that it is significant (Hair et al., 2011). Additionally, in assessing the hypotheses, the probability value ( $p$-value) is utilised. The $p$-value quantitatively measures the numerical significance of a hypothesis and a p-value $<0.05$ implies that the hypothesis is significant (Ifinedo, 2011). In this study, the $\mathrm{R}^{2}$ for the main model is recorded as 0.312 , exceeding the recommended 0.10 threshold (Hair et al., 2011). Table 5 illustrates that TQM and organisational performance has a positive significant relationship $(\beta=0.522$, $\mathrm{t}=5.560, \mathrm{p}<0.001)$. Specifically, customer focus $(\beta=0.207, \mathrm{t}=2.101$, $\mathrm{p}<0.05)$ and service design $(\beta=0.418, \mathrm{t}=3.786, \mathrm{p}<0.001)$ have also positively and significantly affected organisational performance. Hence, $\mathrm{H}_{1}, \mathrm{H}_{1 \mathrm{a}}$ and $\mathrm{H}_{1 \mathrm{~b}}$ are accepted.

To test the moderating effect of role of management accountant, interaction effects were computed through the product indicator approach for the reflective construct and the two stage procedure for the formative construct. The significance of the interaction effect was assessed using a bootstrapping procedure (5,000 resamples). This method was 
Table 5: Path Coefficient After Bootstrapping

\begin{tabular}{lcccccc}
\hline Path & $\begin{array}{c}\text { Beta } \\
\text { Score }\end{array}$ & $\begin{array}{c}\text { Sample } \\
\text { Mean (M) }\end{array}$ & $\begin{array}{c}\text { Standard } \\
\text { Error }\end{array}$ & $\begin{array}{c}\mathrm{t}- \\
\text { Value }\end{array}$ & $\begin{array}{c}\text { p- } \\
\text { Value }\end{array}$ & Results \\
\hline $\mathrm{TQM} \rightarrow$ OP & 0.522 & 0.512 & 0.094 & 5.560 & $<0.001$ & Accepted \\
$\mathrm{CF} \rightarrow$ OP & 0.207 & 0.211 & 0.098 & 2.101 & $<0.050$ & Accepted \\
$\mathrm{SD} \rightarrow$ OP & 0.418 & 0.426 & 0.110 & 3.786 & $<0.001$ & Accepted \\
$\mathrm{TQM}$ * ROMA $\rightarrow$ OP & 0.005 & 0.014 & 0.091 & 0.059 & 0.953 & Rejected \\
\hline
\end{tabular}

Note: $\mathrm{TQM}=$ Total Quality Management, $\mathrm{OP}=$ Organisational Performance, $\mathrm{CF}=$ Customer Focus, SD = Service Design, ROMA = Role of Management Accountant.

validated by Hair et al. (2011) as an applicable way to evaluate path models with latent variable interactions. The $\mathrm{R}^{2}$ increases from 0.312 (main effect model) to 0.314 (interaction effects model). Although the $\mathrm{R}^{2}$ value is increased, the path coefficient $(\beta=0.005, t=0.059, p=0.953)$ is not significant, indicating that the role of management accountant as a moderator between TQM and organisational performance is not substantial. Hence, $\mathrm{H}_{2}$ is rejected.

\section{Discussion and Conclusions}

This study focuses on the service industry of Malaysia, one of the country's largest economic contributors. It employs RBV theory to conceptualise the relationship between TQM, organisational performance and the role of management accountant.

Previous studies (Joiner, 2007; Al-Dhaafri et al., 2016; Meftah Abusa \& Gibson, 2013) which looked at the association between TQM and organisational performance had been inconclusive. In the context of our study, the results reveal that TQM and organisational performance has a significant relationship $(\beta=0.522, \mathrm{t}=5.560, \mathrm{p}<$ 0.001). Our finding is observed to be similar to those of Chong and Rundus (2004), Psomas and Jaca (2016) and Idris (2011). Earlier studies (Chenhall, 1997; Abdullah, Uli, \& Tari, 2008) have also emphasised that TQM provides the opportunity for organisations to improve their competitiveness. Likewise, Kober et al. (2012) and Amir and Reiche (2013) have also concurred that TQM should improve the quality of services and bring a range of performance benefits to organisations. Following the RBV theory, this study has considered TQM as a resource that has a positive influence on the competitive advantage of service 
organisations in Malaysia. Thus, this implies that TQM is an effective management accounting practice which can improve the organisational performance of the service industry. The two features of TQM practice that are examined in this study comprise of customer focus and service design and our results show that customer focus and organisational performance have a significant positive association $(\beta=0.207, t=2.101$, $\mathrm{p}<0.05)$. Thus, it can be inferred that customer focus is a key determinant contributing to organisational performance. This has been endorsed by prior findings (Meftah Abusa \& Gibson, 2013; Sadikoglu \& Olcay, 2014; Psomas \& Jaca, 2016).

The outcome generated is beneficial to companies because customer focus facilitates the in-depth understanding of the requirements and expectations of customers, hence it would facilitate companies in figuring what needs to be done to address customer satisfaction. The results of our study are consistent with the findings of Tsang and Antony (2001) who revealed that the most vital practice of TQM was customer focus, particularly for service companies. This is because customer service is often an issue that needs to be addressed satisfactorily within service companies so as to increase their market shares.

The findings of this study has also demonstrated that service design affects organisational performance significantly $(\beta=0.418, \mathrm{t}=$ $3.786, \mathrm{p}<0.001)$. Service design is also the main factor for explaining organisational performance. The results of our study are consistent with those of Kaynak (2003) and Baird et al. (2011) who noted that effective service design is an important differentiation tool to enhance performance, and to gain a competitive edge. Flynn et al. (1994) also mentioned that service design leads to an increased market share while Calabrese and Corbò (2015) stated that good service design may likely determine business excellence. Nonetheless, our findings are contradictory to those of Brah et al. (2000) and Talib et al. (2013). In the context of Malaysia, service design positively influenced the organisational performance of the service companies in our study.

In looking at the moderating effect of the role of the management accountant, our findings reveal that the management accountant's role did not moderate the association between TQM and organisational performance $(\beta=0.005, t=0.059, p=0.953)$. It is observed that even without the role of the management accountant, TQM significantly affects organisational performance. This finding is contradictory to those of Cockrell and Meyer (2012), Hoque and Alam (1999), and Sharma et al. (2010) who uncovered that the management accountant is one of the 
quality team members who participated greatly in TQM practices of the firms as part of his/her tasks.

Previous studies (Hamilton-Smith \& Morris, 1993; Margavio et al., 1995) have also reported that management accountants could assist the management in the implementation of TQM and other quality strategies. This was confirmed by Fowler (1999), Sharma et al. (2010) and Hoque and Alam (1999). Furthermore, Cockrell and Meyer (2012) had also stated that management accountants have the specific qualification to function in TQM practices besides enabling organisations to achieve greater organisational performance. Conversely, our study reveals that the role of the management accountant did not significantly affect the association between TQM and organisational performance. The contradictory findings found in the current study could be due to several reasons. First, the role of the management accountant is measured by five strategic roles - advisor, business analyst, business partner, value creator and decision enabler. The traditional role of the management accountant as an individual who collected, interpreted and disclosed financial data to the organisation is not considered. Secondly, based on the descriptive analysis revealed in this study, it is observed that the mean score for the role of the management accountant is 3.528, which is considered as marginal. The marginal role of the management accountant did not enhance the association between TQM and organisational performance; hence, there is no moderating effect on the association found in this study. Third, the results derived from our study may be attributed to the lack of control imposed on the size of the organisations that participated in this study. Although the effect of the role of management accountant is not significant, the increase in $\mathrm{R}^{2}$ values of 0.312 (main effect model) to 0.314 (interaction effect model) implies that the role of the management accountant in the service companies of Malaysia can be greatly improved. The strategic roles of the management accountant in the service companies of Malaysia may contribute positively towards the association between the TQM and organisational performance.

\section{Implications and Directions for Future Research}

From the outcomes generated, a few implications can be derived. First, the results of this study could be used to facilitate the application of TQM in service industries as a measure to enhance organisational performance. It seems apparent that organisations need to focus on 
customer needs and demands in order to remain sustainable and successful. One way of achieving this is by integrating customer feedback into the service design (Mahmood et al., 2014). Based on this, it is recommended that managers of service organisations maintain a high level of customer focus, and service design practices within their organisations. Second, the results of this study can help managers of service organisations to determine the roles to be played by management accountants, as these roles may affect the success of TQM. The management accounting profession is evolving, and changing in terms of the role and tasks due to environmental changes such as globalisation, intense competitiveness, and advances in information technology followed by organisational factors, such as product/service quality, new management styles, and customer expectations (Zainuddin \& Sulaiman 2016). Third, the revelation of the significant association between TQM practices and organisational performance proved that service companies need to concentrate on these dimensions if they want to improve their performance through adopting TQM. The necessity of service firms to compete, and to sustain themselves in today's global economic environment that is challenged by economic recession highlights the value of the practical contributions of this study.

In addition, this study has also made several theoretical contributions by providing empirical evidence concerning TQM practices in service organisations in Malaysia. Despite being identified as one of the prominent sectors that is likely to contribute towards Malaysia becoming a developed economy in 2020, the service sector in this country, in terms of TQM has not received much attention from research. A review of the literature has shown that by giving the service industry the relevant attention, valuable proof of the benefits of TQM can be derived. This can be utilised by service managers to improve their service quality. The findings of this study may help to overcome the limited studies conducted on the service industry and its adoption of TQM in Malaysia.

This study has several limitations. Firstly, this study is restricted to the investigation of the effect of two features of TQM practices on organisation performance - customer focus and product/service design. We also applied only one theoretical framework of the RBV as our framework. Future studies could focus on other aspects of TQM practices and theoretical framework. Secondly, this study only examined the service industry. As such, the findings cannot be generalised to other industries. Therefore, future research may consider looking at other service and manufacturing industries. Thirdly, this study has 
used the questionnaire survey as a method for data collection. The test of causality was not conducted in view of the cross-sectional data utilisation. Hence, analysis on the time sequence of the relationship between the variables could not be performed. Future research could use the longitudinal research design to provide the causation evidence. To have a better understanding of the issues involving TQM practices, an in-depth interview including case studies could be conducted as alternative data collection approaches.

\section{References}

Abdullah, M.M., Uli, J., \& Tari, J.J. (2008). The influence of soft factors on quality improvement and performance: Perceptions from managers. The TQM Journal, 20(5), 436-452. http://dx.doi.org/10.1108/17542730810898412

Akio, T. (2005). The critical assessment of the resource-based view of strategic management: The source of heterogeneity of the firm. Ritsumeikan International Affairs, 3, 125-150.

Al-Dhaafri H.S., Al-Swidi, A.K., \& Yusoff, R.Z.B. (2016). The mediating role of total quality management between the entrepreneurial orientation and the organizational performance. The TQM Journal, 28(1), 89-111. http://dx.doi. org/10.1108/TQM-03-2014-0033

Albright, T., \& Lam, M. (2006). Managerial accounting and continuous improvement initiatives: A retrospective and framework. Journal of Managerial Issues, 18(2), 157-174.

Amir Bolboli, S., \& Reiche, M. (2013). A model for sustainable business excellence: Implementation and the roadmap. The TQM Journal, 25(4), 331346. http:// dx.doi.org/10.1108/17542731311314845

Amit, R., \& Schoemaker, P.J.H. (1993). Strategic assets and organizational rent. Strategic Management Journal, 14(1), 33-46. http://dx.doi.org/10.1002/smj. 4250140105

Annamalai, C., \& Ramayah, T. (2013). Does the organizational culture act as a moderator in Indian enterprise resource planning (ERP) projects? An empirical study. Journal of Manufacturing Technology Management, 24(4), 555587. http://dx.doi.org/10.1108/17410381311327404

Ayedh, A., \& Houssem, E. (2015). The impact of advance management accounting techniques on performance: The case of Malaysia. Middle East Journal of Business, 10(2), 3-13. http:/ / dx.doi.org/10.5742/MEJB.2015.92633

Baird, K., Jia Hu, K., \& Reeve, R. (2011). The relationships between organizational culture, total quality management practices and operational performance. International Journal of Operations \& Production Management, 31(7), 789-814. http://dx.doi.org/10.1108/01443571111144850

Barney, J. (1991). Firm resources and sustained competitive advantage. Journal of Management, 17(1), 99-120. http://dx.doi.org/10.1177/014920639101700108 
Bon, A.T., \& Mustafa, E.M. (2013). Impact of total quality management on innovation in service organizations: Literature review and new conceptual framework. Procedia Engineering, 53, 516-529. http://dx.doi.org/10.1016/j. proeng.2013.02.067

Brah, S.A., Wong, L.J., \& Madhu Rao, B. (2000). TQM and business performance in the service sector: A Singapore study. International Journal of Operations \& Production Management, 20(11), 1293-1312. http://dx.doi. org/10.1108/01443570010348262

Bryman, A., \& Bell, E. (2011). Business research methods (3rd Ed.). New York, NY: Oxford University Press Inc.

Byrne, S., \& Pierce, B. (2007). Towards a more comprehensive understanding of the roles of management accountants. European Accounting Review, 16(3), 469-498. http:/ / dx.doi.org/10.1080/09638180701507114

Calabrese, A., \& Corbò, M. (2015). Design and blueprinting for total quality management implementation in service organizations. Total Quality Management $\mathcal{E}$ Business Excellence, 26(7-8), 719-732. http://dx.doi.org/10.1080/ 14783363.2014.881970

Camisón, C., \& López, A. (2010). An examination of the relationship between manufacturing flexibility and firm performance: The mediating role of innovation. International Journal of Operations $\mathcal{E}$ Production Management, 30(8), 853-878. http:/ / dx.doi.org/10.1108/01443571011068199

Chen, Y. (2016). Lean TQM - innovating TQM to TVM (Total Value Management). Journal of Mathematics and Statistical Science, 2(7), 400-411.

Chenhall, R.H. (1997). Reliance on manufacturing performance measures, total quality management and organizational performance. Management Accounting Research, 8(2), 187-206. http:/ / dx.doi.org/10.1006/mare.1996.0038

Chong, V.K., \& Rundus, M.J. (2004). Total quality management, market competition and organizational performance. The British Accounting Review, 36(2), 155-172. http:/ / dx.doi.org/10.1016/j.bar.2003.10.006

Cockrell, S.R., \& Meyer, D. (2012). The role of the management accountant in total quality management. Franklin Business $\mathcal{E}$ Law Journal, 2012(4), 1-18.

Collins, E., Lawrence, S., Roper, J., \& Haar, J. (2011). Sustainability and the role of the management accountant. CIMA Research Executive Summary Series, 7(14), 1-11.

Coo, L.S., \& Verma, R. (2002). Exploring the linkages between quality system, service quality, and performance excellence: Service providers' perspectives. Quality Management Journal, 9(2), 44-56. http://dx.doi.org/10.1080/ 10686967.2002.11919009

Corredor, P., \& Goñi, S. (2011). TQM and performance: Is the relationship so obvious? Journal of Business Research, 64(8), 830-838. http://dx.doi. org/10.1016/j.jbusres.2010.10.002

De Loo, I., Verstegen, B., \& Swagerman, D. (2011). Understanding the roles of management accountants. European Business Review, 23(3), 287-313. http:/ / dx.doi.org/10.1108/09555341111130263 
Dubey, R. (2015). An insight on soft TQM practices and their impact on cement manufacturing firm's performance: Does size of the cement manufacturing firm matter? Business Process Management Journal, 21(1), 2-24. http:/ / dx.doi. org/10.1108/BPMJ-09-2013-0125

Dunk, A.S. (2002). Product quality, environmental accounting and quality performance. Accounting, Auditing \& Accountability Journal, 15(5), 719-732. http:/ / dx.doi.org/10.1108/09513570210448975

Emsley, D. (2008). Different interpretations of a "fixed" concept: Examining Juran's cost of quality from an actor-network perspective. Accounting, Auditing $\mathcal{E}$ Accountability Journal, 21(3), 375-397. http://dx.doi.org/ 10.1108/09513570810863978

Flynn, B.B., Sakakibara, S., \& Schroeder, R.G. (1995). Relationship between JIT and TQM: practices and performance. Academy of management Journal, 38(5), 1325-1360. http://dx.doi.org/10.5465/256860

Flynn, B.B., Schroeder, R.G., \& Sakakibara, S. (1994). A framework for quality management research and an associated measurement instrument. Journal of Operations Management, 11(4), 339-366. http:/ /dx.doi.org/10.1016/S02726963(97)90004-8

Fornell, C., \& Larcker, D.F. (1981). Evaluating structural equation models with unobservable variables and measurement error. Journal of Marketing Research, 18(1), 39-50. http://dx.doi.org/10.1177/002224378101800104

Foss, N.J. (1997). Resources, firms, and strategies: A reader in the resource-based perspective. New York, NY: Oxford University Press.

Fowler, C.J. (1999). The management accountant's role in quality management: A Queensland perspective. International Journal of Applied Quality Management, 2(1), 41-57. http:/ / dx.doi.org/10.1016/S1096-4738(99)80003-7

Gefen, D., \& Straub, D. (2005). A practical guide to factorial validity using PLSGraph: Tutorial and annotated example. Communications of the Association for Information systems, 16, 91-109. http:/ / dx.doi.org/10.17705/1CAIS.01605

Goretzki, L., Strauss, E., \& Weber, J. (2013). An institutional perspective on the changes in management accountants' professional role. Management Accounting Research, 24(1), 41-63. http:/ / dx.doi.org/10.1016/j.mar.2012.11.002

Gurd, B., Smith, M. \& Swaffer, R. (2002). Factors impacting on accounting lag: An exploratory study of responding to TQM. The British Accounting Review, 34(3), 205-221. http://dx.doi.org/10.1006/bare.2002.0198

Hair, J.F., Ringle, C.M., \& Sarstedt, M. (2011). PLS-SEM: Indeed a silver bullet. Journal of Marketing Theory and Practice, 19(2), 139-152. http://dx.doi. org/10.2753/MTP1069-6679190202

Hamilton-Smith, K., \& Morris, T. (1993). Market-driven quality: What management accountants should know. CMA - the Management Accounting Magazine, 67(4), 23-25.

Hamza, M., \& Al-Kassasr, T.A. (2015). Studying the accounting information role for the industrial companies' attitudes towards the implementation of total 
quality management system (Syrian Case). Accounting and Finance Research, $4(2), 34-49$.

Hasan, M., \& Kerr, R. (2003). The relationship between total quality management practices and organizational performance in service organizations. The TQM Magazine, 15(4), 286-291. http://dx.doi.org/10.1108/ 09544780310486191

Hiebl, M.R., Duller, C., \& Feldbauer-Durstmuller, B. (2012). Do management accountants play a different role in family firms? Empirical evidence on management accountants' qualifications and roles in family and nonfamily firms. International Journal of Business Research, 12(2), 94-103.

Hoque, Z., \& Alam, M. (1999). TQM adoption, institutionalism and changes in management accounting systems: A case study. Accounting and Business Research, 29(3), 199-210. http://dx.doi.org/10.1080/00014788.1999.9729580

Idris, F. (2011). Total quality management (TQM) and sustainable company performances: Examining the relationship in Malaysian firms. International Journal of Business and Society, 12(1), 31-52.

Ifinedo, P. (2011). An empirical analysis of factors influencing Internet/ebusiness technologies adoption by SMEs in Canada. International Journal of Information Technology \& Decision Making, 10(4), 731-766. http://dx.doi. org/10.1142/S0219622011004543

Ismail, R., Yussof, I., \& Uddin, N. (2012). Analysis of labour requirements in the Malaysian services sector. International Journal of Business and Management Science, 15(1), 19-38.

Ittner, C.D., \& Larcker, D.F. (1996). Measuring the impact of quality initiatives on firm financial performance. Advances in the Management of Organizational Quality, 1(1), 1-37.

Ittner, C.D., \& Larcker, D.F. (2001). Assessing empirical research in managerial accounting: A value-based management perspective. Journal of Accounting and Economics, 32(1-3), 349-410. http://dx.doi.org/10.1016/S0165-4101(01) 00026-X

Joiner, T.A. (2007). Total quality management and performance: The role of organization support and co-worker support. International Journal of Quality $\mathcal{E}$ Reliability Management, 24(6), 617-627. http://dx.doi.org/10.1108/ 02656710710757808

Kamboj, S., Goyal, P., \& Rahman, Z. (2015). A resource-based view on marketing capability, operations capability and financial performance: An empirical examination of mediating role. Procedia-Social and Behavioral Sciences, 189, 406-415. http://dx.doi.org/10.1016/j.sbspro.2015.03.201

Kaynak, H. (2003). The relationship between total quality management practices and their effects on firm performance. Journal of Operations Management, 21(4), 405-435. http://dx.doi.org/10.1016/S0272-6963(03)00004-4

Kent, R. (2001). Data construction and data analysis for survey research. New York, NY: Macmillan. 
Krejcie, R.V., \& Morgan, D.W. (1970). Determining sample size for research activities. Education and Psychological Measurement, 30(3), 607-610. http:// dx.doi.org/10.1177/001316447003000308

Ko, D.G., Kirsch, L.J., \& King, W.R. (2005). Antecedents of knowledge transfer from consultants to clients in enterprise system implementations. MIS Quarterly, 29(1),59-85.

Kober, R., Subraamanniam, T., \& Watson, J. (2012). The impact of total quality management adoption on small and medium enterprises' financial performance. Accounting $\mathcal{E}$ Finance, 52(2), 421-438. http://dx.doi.org/10.1111/ j.1467-629X.2011.00402.x

Kumar, R., Garg, D. \& Garg, T. (2011). TQM success factors in North Indian manufacturing and service industries. The TQM Journal, 23(1), 36-46. http://dx.doi.org/10.1108/17542731111097470

Lam, S.Y., Lee, V.H., Ooi, K.B., \& Phusavat, K. (2012). A structural equation model of TQM, market orientation and service quality: Evidence from a developing nation. Managing Service Quality: An International Journal, 22(3), 281-309. http://dx.doi.org/10.1108/09604521211230996

Mahmood, K., Mahmood, I., Qureshi, A., \& Nisar, A. (2014). An empirical study on measurement of performance through TQM in Pakistani aviation manufacturing industry. International Journal of Quality \& Reliability Management, 31(6), 665-680. http://dx.doi.org/10.1108/IJQRM-03-2012-0041

Mahmud, N., \& Hilmi, M.F. (2014). TQM and Malaysian SMEs performance: The mediating roles of organization learning. Procedia - Social and Behavioral Sciences, 130(May), 216-225. http:// dx.doi.org/10.1016/j.sbspro.2014.04.026

Malmi, T., Seppala, T., \& Rantanen, M. (2001). The practice of management accounting in Finland - A Change? Liiketaloudellinen aikakauskirja, 4(1), 480501.

Manners, J.G.E. (2006). Six levels of financial knowledge. Strategic Finance, 8(2), 32-39.

Margavio, G., Margavio, T., \& Fink, R. (1995). Managing the cost of quality in the era of continuous improvement. CMA - The Management Accounting Magazine, 69(1), 29-31.

Martín-De Castro, G., Delgado-Verde, M., Navas-López, J.E., \& Cruz-González, J. (2013). The moderating role of innovation culture in the relationship between knowledge assets and product innovation. Technological Forecasting and Social Change, 80(2), 351-363. http://dx.doi.org/10.1016/j.techfore. 2012.08.012

Meftah Abusa, F., \& Gibson, P. (2013). Experiences of TQM elements on organizational performance and future opportunities for a developing country. International Journal of Quality \& Reliability Management, 30(9), 920941. http://dx.doi.org/10.1108/IJQRM-07-2012-0106

Ministry of International Trade and Industry (MITI) (2013). Services sector in Malaysia. Retrieved from http://myservices.miti.gov.my/about-my-services 
Ministry of Finance Malaysia (2016). Economic report 2015/2016. Retrieved from https://www.treasury.gov.my/index.php/en/archives/2015/economicreport.

Mistry, V., Sharma, U., \& Low, M. (2014). Management accountants' perception of their role in accounting for sustainable development: An exploratory study. Pacific Accounting Review, 26(1-2), 112-133. http://dx.doi.org/ 10.1108/PAR-06-2013-0052

Mohanty, R., \& Behera, A. (1996). TQM in the service sector. Work Study, 45(3), 13-17. http:/ / dx.doi.org/10.1108/00438029610115479

Mohd Amir, A., Nik Ahmad, N.N., \& Har Sani Mohamad, M. (2010). An investigation on PMS attributes in service organizations in Malaysia. International Journal of Productivity and Performance Management, 59(8), 734756. http:/ / dx.doi.org/10.1108/17410401011089445

Mosadeghrad, A.M. (2013). Obstacles to TQM success in health care systems. International Journal of Health Care Quality Assurance, 26(2), 147-173. http:/ / dx.doi.org/10.1108/09526861311297352

Mosadeghrad, A.M. (2014). Essentials of total quality management: A metaanalysis. International Journal of Health Care Quality Assurance, 27(6), 544-558. http:/dx.doi.org/10.1108/IJHCQA-07-2013-0082

Muhammad Zawawi, N.H., \& Hoque, Z. (2010). Research in management accounting innovations: An overview of its recent development. Qualitative Research in Accounting $\mathcal{E}$ Management, 7(4), 505-568. http://dx.doi.org/ 10.1108/11766091011094554

Muzamil Naqshbandi, M., \& Idris, F. (2012). Competitive priorities in Malaysian service industry. Business Strategy Series, 13(6), 263-273. http://dx.doi. org/10.1108/17515631211286100

Nicolaou, N., \& Kentas, G. (2017). Total quality management implementation failure reasons in healthcare sector. Journal of Health Science, 5, 110-113. http:/ / dx.doi.org/10.17265/2328-7136/2017.02.007

Nuhu, N.A., Baird, K., \& Appuhami, R. (2016). The association between the use of management accounting practices with organizational change and organizational performance. Advances in Management Accounting, 26, 67-98. http://dx.doi.org/10.1108/S1474-787120150000026003

Ochieng, J., Muturi, D., \& Njihia, S. (2015). The Impact of ISO 9001 Implementation on organisational perfromance in Kenya. The TQM Journal, 27(6), 761777. http:/ / dx.doi.org/10.1108/TQM-06-2015-0071

Ooi, K-B., Lin, B., Tan, B-I., \& Chong, A.Y-L. (2011). Are TQM practices supporting customer satisfaction and service quality? Journal of Services Marketing, 25(6), 410-419. http://dx.doi.org/10.1108/08876041111161005

Ortega, M.J.R. (2010). Competitive strategies and firm performance: Technological capabilities' moderating roles. Journal of Business Research, 63(12), 1273-1281. http:/ / dx.doi.org/10.1016/j.jbusres.2009.09.007

Paulsson, G. (2012). The role of management accountants in new public management. Financial Accountability E Management, 28(4), 378-394. http:/ / dx.doi.org/10.1111/j.1468-0408.2012.00552.x 
Powell, T.C. (1995). Total quality management as competitive advantage: A review and empirical study. Strategic Management Journal, 16(1), 15-37. http://dx.doi.org/10.1002/smj.4250160105.

Psomas, E.L., \& Jaca, C. (2016). The impact of total quality management on service company performance: Evidence from Spain. International Journal of Quality \& Reliability Management, 33(3), 380-398. http://dx.doi.org/ 10.1108/IJQRM-07-2014-0090

Rahman, S., \& Ahmed, J.U. (2012). An evaluation of the changing role of management accountants in recent years. Indus Journal of Management $\mathcal{E}$ Social Science, 6(1), 18-30.

Ramayah, T., Samat, N., \& Lo, M.C. (2011). Market orientation, service quality and organizational performance in service organizations in Malaysia. Asia-Pacific Journal of Business Administration, 3(1), 8-27. http://dx.doi. org/10.1108/17574321111116379

Ramli, A., Zainuddin, Z.N., Sulaiman, S., \& Muda, R. (2013). Changing roles of management accountants in Malaysian companies: A preliminary study. International Journal of Finance and Accounting, 2(2), 89-93. http://dx.doi. org/10.5923/j.ijfa.20130202.06

Ross, L., \& Kovachev, I. (2009). Management accounting tools for today and tomorrow. London: Chartered Institute Management Accountant.

Sadikoglu, E., \& Olcay, H. (2014). The effects of total quality management practices on performance and the reasons of and the barriers to TQM practices in Turkey. Advances in Decision Sciences, 2014, 1-17. http:/ /dx.doi. org/10.1155/2014/537605

Sadikoglu, E., \& Zehir, C. (2010). Investigating the effects of innovation and employee performance on the relationship between total quality management practices and firm performance: An empirical study of Turkish firms. International Journal of Production Economics, 127(1), 13-26. http://dx.doi.org/10.1016/j.ijpe.2010.02.013

Seetharaman, A., Sreenivasan, J., \& Lim, P.B. (2006). Critical success factors of total quality management. Quality and Quantity, 40(5), 675-695. http:// dx.doi.org/10.1007/s11135-005-1097-2

Sharma, U., Lawrence, S., \& Lowe, A. (2010). Institutional contradiction and management control innovation: A field study of total quality management practices in a privatized telecommunication company. Management Accounting Research, 21(4), 251-264. http://dx.doi.org/10.1016/j.mar.2010. 03.005

Sharma, U. (2000). Management accounting and control system changes in a public sector context: A case study (Working Paper). Suva, Fiji: Department of Accounting and Financial Management, University of the South Pacific.

Silvestro, R. (1998). The manufacturing TQM and service quality literatures: Synergistic or conflicting paradigms? International Journal of Quality $\mathcal{E}$ Reliability Management 15(3), 303-328. http://dx.doi.org/10.1108/ 02656719810198917 
Sit, W-Y., Ooi, K-B., Lin, B., \& Chong, A.Y-L. (2009). TQM and customer satisfaction in Malaysia's service sector. Industrial Management $\mathcal{E}$ Data Systems, 109(7), 957-975. http://dx.doi.org/10.1108/02635570910982300

Sohail, M.S., \& Teo, B.H. (2003). TQM practices and organizational performances of SMEs in Malaysia: Some empirical observations. Benchmarking: An International Journal, 10(1), 37-53 http://dx.doi.org/10.1108/14635770310 457539

Soltanizadeh, S., Abdul Rasid, S.Z., Mottaghi Golshan, N., \& Wan Ismail, W.K. (2016). Business strategy, enterprise risk management and organizational performance. Management Research Review, 39(9), 1016-1033. http://dx.doi. org/10.1108/MRR-05-2015-0107

Straub, D., Bourdreau, M.-C. \& Gefen, D. (2004). Validation guidelines for IS positivist research. Communications of the Association for Information Systems, 13(1), 380-427. http://dx.doi.org/10.17705/1CAIS.01324

Sulaiman, S., Ramli, A., Mitchell, F. (2008). The dynamics of management accounting in Malaysia: A research note. Asia-Pacific Management Accounting Journal, 3(1), 1-19.

Sunarni, C.W. (2013). Management accounting practices and the role of management accountant: Evidence from manufacturing companies throughout Yogyakarta, Indonesia. Review of Integrative Business and Economics Research, 2(2), 616-626.

Sweis, R.J., Mahmoud Saleh, F.I., Dahiyat, S.E., Sweis, N.J., Saleh, R.A., \& Diab, H. (2016). Benchmarking of TQM practices in INGOs: A literature review. Benchmarking: An International Journal 23(1), 236-261. http://dx.doi.org/ 10.1108/BIJ-02-2015-0013

Talib, F., \& Rahman, Z., (2015). Identification and prioritization of barriers to total quality management implementation in service industry, The TQM Journal, 27(5), 591-615. http:// dx.doi.org/10.1108/TQM-11-2013-0122

Talib, F., Rahman, Z., \& Qureshi, M.N. (2013). An empirical investigation of relationship between total quality management practices and quality performance in Indian service companies. International Journal of Quality $\mathcal{E}$ Reliability Management, 30(3), 280-318. http://dx.doi.org/10.1108/ 02656711311299845

Tatikonda, L.U., \& Tatikonda, R.J. (1996). Top ten reasons your TQM effort is failing to improve profit. Production and Inventory Management Journal, $37(3), 5-9$.

Tena, A.B.E., Llusar, J.C.B., \& Puig, V.R. (2001). Measuring the relationship between total quality management and sustainable competitive advantage: A resource-based view. Total Quality Management, 12(7-8), 932-938. http:// dx.doi.org/10.1080/09544120100000018

Terzvioski, M. (2006). Quality management practices and their relationship with customer satisfaction and productivity improvement. Management Research News, 29(7), 414-424. http:/ /dx.doi.org/10.1108/01409170610690871 
Tsang, J.H.E., \& Antony, J. (2001), TQM in UK service organisations: Some findings from a survey. Managing Service Quality, 11(2), 132-141. http:// dx.doi.org/10.1108/09604520110387293

Tuanmat, T., \& Smith, M. (2011). Changes in management accounting practices in Malaysia. Asian Review of Accounting, 19(3), 221-242. http://dx.doi. org/10.1108/13217341111185146

Wade, M., \& Hulland J. (2004). Review: The resource-based view and information systems research: Review, extension, and suggestions for future research. MIS quarterly, 28(1), 107-142.

Wickramasinghe, D., \& Alawattage, C. (2007). Management accounting change: Approaches and perspectives. New York, NY: Routledge.

Yasin, M.M., Alavi, J., Kunt, M., \& Zimmerer, T.W. (2004). TQM practices in service organizations: An exploratory study into the implementation, outcome and effectiveness. Managing Service Quality: An International Journal, 14(5), 377-389. http://dx.doi.org/10.1108/09604520410557985

Yazdifar, H., Askarany, D., \& Askary, S. (2008). Management accountants' role in dependent and independent companies: Does ownership matter? Journal of Accounting - Business \& Management, 15(2), 1-21.

Yazdifar, H., \& Tsamenyi, M. (2005). Management accounting change and the changing roles of management accountants: A comparative analysis between dependent and independent organizations. Journal of Accounting \& Organizational Change, 1(2), 180-198. http://dx.doi.org/ $10.1108 / 18325910510635353$

Yunis, M., Jung, J. \& Chen, S. (2013). TQM, strategy, and performance: A firmlevel analysis. International Journal of Quality \& Reliability Management, 30(6), 690-714. http://dx.doi.org/10.1108/02656711311325638

Zainuddin, Z.N., \& Sulaiman, S. (2016). Challenges faced by management accountants in the 21st Century. Procedia Economics and Finance, 37, 466-470. http://dx.doi.org/10.1016/S2212-5671(16)30153-8 
